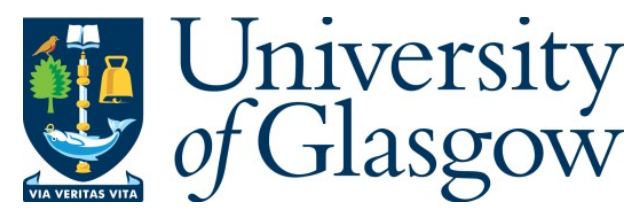

Goldoni, M. and Wilkinson, M. A. (2018) The material constitution. Modern Law Review, 81(4), pp. 567-597. (doi:10.1111/1468-2230.12352).

There may be differences between this version and the published version. You are advised to consult the publisher's version if you wish to cite from it.

This is the peer reviewed version of the following article:

Goldoni, M. and Wilkinson, M. A. (2018) The material constitution. Modern Law Review, 81(4), pp. 567-597, which has been published in final form at

10.1111/1468-2230.12352. This article may be used for non-commercial purposes in accordance with Wiley Terms and Conditions for Self-Archiving.

http://eprints.gla.ac.uk/153227/

Deposited on: 08 December 2017

Enlighten - Research publications by members of the University of Glasgow http://eprints.gla.ac.uk 


\section{The Material Constitution}

\section{INTRODUCTION}

Constitutionalism in Europe is suffering a certain fatigue. Due in part to NorthAmerican influence, constitutional enquiry had become narrowly focused on the protection of constitutional norms and the enforcement of individual rights through the judicial process. The special role played by constitutional courts and the German Constitutional Court in particular underlined an increasingly 'juridical' approach to constitutionalism. ${ }^{1}$ If the constitution was what the court said it was, the task of the constitutional lawyer was to provide normative and hermeneutic guidance for judicial reasoning. This coincided with the broader judicialisation of constitutional politics, aptly characterised by Ran Hirschl as 'juristocracy', but fully embraced by legal constitutionalists as the best institutional arrangement for holding the constitution together and protecting individual rights from political abuse. $^{2}$

The theoretical hegemony of this approach, appositely labelled 'normativism', ${ }^{3}$ can be traced from the beginning of the post-war period through to a triumphant pinnacle at the 'end of history' marked by the fall of the Berlin wall and the collapse of the Soviet Union. But in the wake of 9/11 and the return of states of emergency and states of exception, normativism begins to appear vulnerable. With the inception of the Euro-crisis, the rule of law crisis and more recently the migrant crisis in Europe, it starts to look untenable. ${ }^{4}$ These critical conjunctures show that the normative constitution in general and the protection of rights through judicial means in particular are not self-sustaining. Constitutional history reclaims front stage, if it had ever fully left the theatre. The repercussions of course extend beyond constitutional theorising, as the 'end of history narrative' is discarded, disowned by its inventor, and non-liberal political theory returns to the fore.

\footnotetext{
${ }^{1}$ See e.g. C. Möllers, 'We are (afraid of) the people', in M. Loughlin and N. Walker (eds.) The Paradox of Constitutionalism: Constitutional Power and Constitutional Form (Oxford University Press, 2007) 87 - 107

${ }^{2} \mathrm{R}$ Hirschl, Towards Juristocracy: The Origins and Consequences of the New Constitutionalism (Harvard University Press 2004).

${ }^{3}$ See M. Loughlin, 'The Concept of Constituent Power' (2014) 13 European Journal of Political Theory 218; M. Loughlin and S. Tschorne, 'Public Law' in The Routledge Handbook of Interpretive Studies (Routledge, 2016).

${ }^{4}$ See e.g. J. White, 'Authority after Emergency Rule' (2015) 78 Modern Law Review 585; C Gearty, 'The State of Freedom in Europe' (2015) 21 European Law Journal 706. More generally, see V. Ramraj 'No Doctrine More Pernicious? Emergencies and the Limits of Legality' in Ramraj (ed.) Emergencies and the Limits of Legality (Cambridge University Press, 2008) 3 - 29.
} 
It is no surprise that by the beginning of the millennium a new wave of 'political constitutionalism' had entered the stage. ${ }^{5}$ But, with some notable exceptions, this stream of scholarship remained normative, reductive, formalistic, wedded to individualistic premises, and incapable of offering explanatory conceptual accounts of constitutionalism or of constitutional development. ${ }^{10} \mathrm{It}$ restricted itself to claims about the superiority of parliaments over courts at holding the executive to account and at determining rights disputes, positioning itself normatively against the legal constitutionalist's faith in judicial reasoning, but eschewing issues of constituent power and state theory.

In short, political constitutionalism was insufficiently material. ${ }^{11}$ It remained mute in the face of renewed constitutional crises and political-economic crises of the state and the inter-state system, and impervious to the increasingly fraught nature of the social relations undergirding them. Political and legal constitutionalists alike neglected the material conditions for the emergence and development of a constitutional order, and the material changes that prompt the suspension or modification of formal constitutional norms. To understand these phenomena requires attention to the underlying material context, to the basic political and social conditions of possibility of constitutionalism and the dynamics of constitutional change. Otherwise constitutional theory will have little to say about the most important challenges to constitutional ordering, whether in the shape of the existential crisis of the Eurozone, the fracturing of the political unity of the modern state, or the return of anti-systemic political and social movements.

The material constitution, it is argued here, is not grasped merely by supplementing judicial with political analysis, by exposing the significance of parliamentary authority and the role of executive powers in the governing arrangements of the polity. It is grasped only by properly grappling with the deeper societal context in which formal constitutional development is embedded (or, as the case may be, dis-embedded). It is the purpose of this article to offer a starting point for conceptual enquiry into this material constitution.

The material constitution is clearly complex. To manage complexity and gain an analytical purchase, we identify four key (if not necessarily exclusive) 'layers' of the constitution: political unity, the dominant form of which remains the modern nation-state; a set of institutions, including but not limited to formal governmental branches such as courts, parliaments, executives, administrations; a network of social relations, including class interests and social movements, and a set of fundamental political objectives (or telor). These make up the four ordering forces of the constitution.

\footnotetext{
${ }^{5}$ Key works are J. Waldron, Law and Disagreement (Oxford University Press, 1999); A. Tomkins, Our Republican Constitution (Hart, 2005); R. Bellamy, Political Constitutionalism (Cambridge University Press, 2007).

${ }^{10}$ Cf K. Ewing, 'The Resilience of the Political Constitution' (2013) 14 German Law Journal 2111; O. Beaud, 'Reframing a debate amongst Americans: Contextualising a Moral Philosophy of Law' (2009) International Journal of Constitutional Law 53 - 68.

11 Cf. P. Minkinnen, 'Political Constitutionalism vs. Political Constitutional Theory: Law, Power and Politics' (2015) 11 International Journal of Constitutional Law 585 - 610.
} 
The paper proceeds as follows. First, we situate the material constitution in the historical context of its earlier iteration, the interwar constitutional theories of Heller and Mortati (part 2). Although departing from the normativism of Kelsen and the decisionism of Schmitt, and offering important insights on which to build, Heller and Mortati fail to provide a full theoretical framework for the material constitution, which needs therefore to be reconstructed (part 3). We then begin this task by outlining each of the four ordering forces of the material constitution in turn (part 4). Finally, we conclude (part 5) by presenting the material constitution neither as a field of extra-juristic knowledge, nor as a straightforward conveyor-belt of legal norms but as internally and dynamically related to the formal constitution.

\section{SITUATING THE MATERIAL CONSTITUTION: THE OLD TRADITION}

The notion of the constitution in a material sense (Verfassung im materiellen Sinne) as distinct from the written document can be found in the work of Hans Kelsen. ${ }^{12}$ But for Kelsen the material constitution amounts merely to the set of norms that authorises law-making, law-interpreting and law-applying powers. He offers an entirely formal definition, 'those norms that refer to the supreme organs and $[\ldots]$ to the relation between subjects and the power of the State'. ${ }^{13}$ This accords with Kelsen's claim that the state is nothing but the 'personification' of a legal order, and his simple assumption of the 'identity' of law and state. ${ }^{14} \mathrm{He}$ rejects any account of the political or social relations behind these norms or of the state as a politico-juristic or sociological entity. ${ }^{15}$ We thus need to move beyond Kelsen in order to capture the underlying material order of the constitution.

To begin this, we can turn to less formalist theories that emerge from Kelsen's contemporaries in the interwar period, to authors who rejected pure normativism, but who also rejected the pure decisionism associated with Carl Schmitt (although, as we examine in the next section, Schmitt's own institutionalist turn offers some important insights). Our points of reference are the works of Herman Heller and Costantino Mortati, both jurists who were steeped in the state theory and institutionalism of their time. Methodologically, this allowed them to thematise the link between constitutional order and society in a way that avoids

${ }^{12}$ H. Kelsen, Allgemeine Staatslehre (Springer, 1925) 252.

13 Ibidem, 252-253. Later, Kelsen will confirm his position on the material constitution in General Theory of Law and State (Harvard University Press, 1945) 124-125.

${ }^{14} \mathrm{H}$. Kelsen, ibid, 181

${ }^{15}$ See, for a discussion of the difference between formal and material constitution in Kelsen's work, L. Vinx, Hans Kelsen's Pure Theory of Law (Oxford University Press, 2007) 158-160. Vinx has also shown that by reading together Kelsen's political theory and legal philosophy, it is possible to connect his pure theory of law to his concerns about social order. Vinx is right to identify Kelsen's legal philosophy as the complement to his theory of democracy and as a way to understand lawmaking as a channel of composition among different and fragmented interests. Our conception of the material constitution, outlined below, rejects this proceduralism. 
the orthodox liberal juxtaposition between law and politics, or between State and civil society. Forged in the crucible of interwar Germany and Italy, their theories must be understood with those turbulent contexts in mind. But they represent, in nuce, the concern to develop a fuller material account of the constitution and are worth exploring in their own right.

\section{(a) Heller: Political Democracy and Social Homogeneity}

If Kelsen and Schmitt were two archetypal thinkers of normativism and decisionism respectively, then Herman Heller was their neglected interlocutor who offered a 'third alternative. ${ }^{16}$ For Heller, a dialectical approach to the constitution is necessary because political power always aspires to the legal form posited and secured by the organs of the state, just as legal form requires the support of political power to sustain it in actuality. Heller's alternative depended not just on presenting law and politics as interdependent, however, but as driven by a social dynamic, in the sense that the state - or any constitutional order -must not only seek legitimacy or ethical justification but also convey the realistic possibility of some success in this task. ${ }^{17}$ The nature of this ethical grounding is not precisely specified, but two things can be stated at the outset: it goes to the democratic quality of a regime and the prospect of attaining some degree of socio-economic equality.

The constitution, according to Heller, depends on a material order. It is formed not only out of legislative action, tradition, and political expediency, but also constellations of social and economic power. ${ }^{18}$ Viewed historically, the constitution might then appear as a mere modus vivendi, the result of a political compromise or fortuitous balance of interests. But for Heller, it must have a normative quality. ${ }^{19}$

'Efficacy and validity, the "is" and the "ought" of the constitution' must be 'logically distinguished', but, 'they nevertheless apply to the same constitutional reality, in which the statement of one always at the same time asserts the other. ${ }^{20}$ This can equally be applied to the subject of the constitution-giving power, the pouvoir constituant. The pouvoir constituant - whether 'the prince' or 'the people' - only has the power of constitution-giving on the basis of a normative authority. ${ }^{21}$

\footnotetext{
${ }^{16}$ H. Heller, 'Political Democracy and Social Homogeneity' in A. Jacobson and B. Schlink (eds) Weimar: A Jurisprudence of Crisis (University of California Press, 2000) 272.

${ }^{17}$ Because of this relationship between law and politics, and 'on account of its social function', Heller argues that 'each state power must strive not only for legality in the legal technical sense, but also, for the sake of its self-preservation, for an ethical justification of its positive legal or conventional norms, i.e. for legitimacy' ibid, 272. See further Dyzenhaus, 'Hermann Heller and the Legitimacy of Legality’ (1996) Oxford Journal of Legal Studies 641 - 666.

${ }^{18}$ Heller above, 275-6

$19 \mathrm{ibid}, 277$. Heller notes that the idea of the constituent power can as much be a reactionary as a revolutionary doctrine.

20 ibid, 277

21 'The prince possesses constitution-giving power, not because he has it existentially, but only on the "basis of the normative order of hereditary succession, and hence, as legal power...
} 
This normative quality is framed not in the (Kelsenian) sense of authorisation by a previously valid norm (which would only lead to the infinite regression closed by the Grundnorm), but on the basis of ethical principles in the service of the common good. ${ }^{22}$ Rejecting both Schmitt's 'norm-less power' and Kelsen's 'powerless norm', Heller strives for a middle-way. ${ }^{23} \mathrm{He}$ argues that the constitution requires at least one decisive section of those subject to its power to comply with it, not just out of self-interest or habituation, but because they accept it, without explaining what section of the population would be decisive or what acceptance means. ${ }^{25}$

But by linking constitutional authority with social acceptance, constitutional enquiry is forced to confront a theory of democracy. "The law of democracy' after all, Heller notes, 'attributes the formation of state power to 'the people". ${ }^{26}$ This was the case explicitly with the Weimer constitution itself. And in practice, it guaranteed universal suffrage for the first time in German history.

Democracy, for Heller, is not about an 'identity' between rulers and ruled, but it does require a relative social homogeneity. ${ }^{27}$ This can undoubtedly have a cultural, religious or nationalistic element. But ultimately it is a social and economic category. What is decisive is not the ideological superstructure but the reality of socio-economic relations. ${ }^{28}$ There must exist a certain degree of socioeconomic equality - or the prospect of such - for the people as a plurality consciously to form itself into the people as unity. Otherwise, Heller warned, 'the most radical formal equality becomes the most radical inequality, and formal democracy becomes the dictatorship of the ruling class. ${ }^{29}$

The task of political democracy is to manage social heterogeneity and social conflict. There can be no existential assumption of a concrete political order. Heller firmly rejects Schmitt's authoritarian state, a substantive unity based

$[\mathrm{W}]$ ithout a normative act, a mass of human beings has neither a will capable of decision, nor power capable of action and at the very least it has no authority whatsoever.' Ibid, 277.

22 Thus 'to be more than a highly unstable factual situation of superior power, to be valid as lawful order, a constitution needs justification from ethical principles of law.' ibid, 278. Although highlighting the contingence of the ethical order (justice can only be realized by the 'individual conscience'), we are given little guidance as to how to identify it.

${ }^{23}$ For extended discussion see D. Dyzenhaus, Legality and Legitimacy: Carl Schmitt, Hans Kelsen and Hermann Heller in Weimar (Oxford University Press, 1997).

${ }^{25}$ Cf. M. Wilkinson, 'Is Law Morally Risky: Alienation, Acceptance and Hart's Concept of Law View' (2010) OJLS $441-466$.

26273.

${ }^{27}$ Not only Schmitt but also Kelsen argues that a certain homogeneity is necessary for the democratic polity, yet Kelsen explicitly rejects the need for social equality. See H. Kelsen, 'On the Essence and Value of Democracy' in A. Jacobson and B. Schlink (eds), Weimar: A Jurisprudence of Crisis, cit., 84-108.

${ }^{28}$ Heller, above 261. Heller recognizes that the bourgeoisie as a class will attempt to resurrect ideologies, including those of nationalism and of monarchy, in order to maintain its own position of power amid the eternal 'cycle of elites', ibid 261.

${ }^{29} \mathrm{Ibid}, 262$ (a factor which enables him to distinguish the European social problem from the 'Negro Question' in America. He notes that 'nothing is more characteristic of the social disparity which threatens our democracy than the attempt to recast the economic disparity into an anthropological one', ibid 264) 
ultimately on the political-existential logic of who is 'friend and enemy', and in extremis, grounded by the sovereign ('he who decides on the exception'). This is too 'top-down' in its view of constitutional ordering, ignores the dynamics of political will-formation, and comes into direct contradiction with democracy, 'which is supposed to be a conscious process of the formation of political unity from bottom to top'. ${ }^{30}$

For Heller, political unity is not a bare fact of existential recognition of 'we' and 'them'; it is formed, constructed, and mediated through the political process, which channels competing claims over the common good. ${ }^{31}$ For this to happen, institutions, and political parties in particular, are essential. ${ }^{32}$ 'Homogeneity' is something that daily must be formed anew, Heller approving Renan's famous account of national unity as 'un plebiscite de toujours. ${ }^{33}$

The essence of political unity remains elusive, resistant to any straightforward empirical analysis, political resolution, extraordinary, or extraconstitutional decision. ${ }^{34}$ And since the social structure remains necessarily antagonistic, ${ }^{35}$ Heller rejects the utopian socialism of those on the Marxist wing of the German Social Democratic Party (SPD) as well as the conservatism of his authoritarian opponents.

But turning from his state theory to his political commentary, we get a sense of the significance of socio-economic equality for the stability of the constitutional order. Heller signals direct opposition to Schmitt regarding the impact of the domestic political economy of late Weimar on the breakdown of its liberal-democratic regime, as it edged towards authoritarianism before finally collapsing in 1933. Just one year before, Heller took stock of the threat of authoritarianism, a strong conservative state asserting itself in Germany to remedy the perceived impotence of liberal democracy and in particular the weakness and disorder of its parliamentary regime. This brief phase of 'president's cabinets' from 1930-33 witnessed the bypassing of parliamentary authority, government through emergency decrees, drastic cuts to state expenditure, internal devaluation, and a deflationary policy of Germany's central bank, under pressure of servicing its debts. 36

\footnotetext{
${ }^{30}$ Ibid.

31 Ibid, 260.

32 Ibid.

${ }^{33}$ Ibid.

34 Heller: 'One cannot say definitively how this "we-consciousness" is produced and destroyed. All attempts to find the impulse for this consciousness in a single sphere of life have failed and must fail. All that we can rightly know is that in each epoch a correspondence between social being and consciousness - in other words a societal form - emerges, 'ibid, 261.

35 ibid.

36 See Eberhard Kolb, The Weimar Republic 2nd edition tr. P. S. Falla and R. J. Park (Routledge, 2005) 116 - 135. According to Kolb it was supported not only by the Right but by large part of the centre, as well as powerful economic interest groups and the army faction. The fateful transition to authoritarianism, anti-Marxist and anti-parliamentarian in outlook, was coolly planned 'and with the intention of drastically altering the constitutional system and the balance
} 
The turn to a new authoritarianism is not accounted for by the physical or metaphysical allure of the powerful national state and its capacity to restore German pride, national unity and international standing, or 'a belief in the miracles wrought by a dictatorship'. ${ }^{37}$ The issues of reparations and of military parity with France had already been dealt with, or were close to being resolved by the weak Weimar republic. It was, in any case, as Heller notes, the authoritarian German state that had lost the First World War and should have been responsible for the humiliation that followed.

What characterised the new authoritarian state, for Heller, was the domain from which it claimed to extract itself. It was necessary to look, first and foremost, at 'the economic order'. Those, like Carl Schmitt, advocating the authoritarian state as an answer to liberal democracy's weakness were not proffering it to deal with the problem of social-economic inequality. ${ }^{38}$ On the contrary, they were advocating a state, rhetorically at least, that would distance itself from the economic realm. Demanding a separation of the state from the economy would not have come easy to the 'total-authoritarian' Schmitt, Heller suggests. Schmitt's solution was to distinguish between the state that interferes in the economy, which is in fact a weak state, and the 'qualitatively total state', which draws a sharp line of separation vis-à-vis the economy, but uses a heavy fist militarily and mass manipulation in cultural domains. ${ }^{39}$ The strong state feigns to sever its connections with the economy - outside certain limited areas of state monopoly to demonstrate its overwhelming authority. ${ }^{40}$

Heller characterises this new conservatism as marshalled in defence of capitalism against social democracy, reversing a $19^{\text {th }}$ century position when conservatism had protected the feudal order against capitalism. ${ }^{41}$ Representing a further development of national liberalism, it is, Heller concludes, 'to be addressed

of social forces in favor of old elites of the army, bureaucracy and big business', above at 117 118.

${ }^{37}$ H. Heller, 'Authoritarian Liberalism' tr. B. Paulson, S. Paulson and A. Somek (2015 [1933]) European Law Journal 295 - 302, 296.

${ }^{38}$ Heller notes that there could be no 'metaphysico-religious' foundation for the state in Germany because of its religious heterogeneity. This also prevents the State, in Heller's view, from being able to impose a form of cultural community (Kulturgemeinschaft). The national socialist goal of bringing about cultural homogeneity through an authoritarian racial community is considered by Heller too idealistic in the eyes of the German population to be likely to succeed. He briskly - in hindsight, at least, all too briskly - also dismisses as not even serious the idea that the authoritarian state be used to promote a particular racial ideology. Heller, 'Authoritarian Liberalism', above.

${ }^{39}$ The term total state later became used by Forsthoff to polemicise against the substantively empty liberal state. See further K. Tribe, Strategies of Economic Order: German Economic Discourse 1750 - 1950 (Cambridge University Press, 2008) 179 - 180.

40 Schmitt defends this authoritarian liberalism in his address to the Langnamverein. A translation is appended in R. Cristi, Carl Schmitt and Authoritarian Liberalism (University of Wales, 1998). Schmitt permitted its reprinting at least twice, suggesting for Scheuerman that it was a text that was of some significance to him, see Carl Schmitt and the End of Law (Rowman and Littlefield, 1999) 288.

41 On the significance of the Deutsche Nationale Volkspartei, the DNVP, see Kolb, above, 116 120. 
as authoritarian liberalism', its liberalism now economic in substance. ${ }^{42}$ Rather than strengthening national identity to resist the pressures of modernization, bonds of solidarity must be 'loosened', even destroyed, to resist the forces of socialism. ${ }^{43}$ Above all, the objective of the authoritarian liberals, who effectively 'put Hitler into power', was the elimination of social democracy from politics through neutering its parliamentary authority. ${ }^{44}$

Defence of the capitalist form of the economy in an era of mass politics combined with increasing class consciousness required a strong state. ${ }^{45}$ It required not laissez-faire but planning - not the separation of politics and economics, but their intertwinement. This kind of 'neo-liberalism', remarks Heller, could never be maintained in democratic form, however, not least because of the ninety per-cent that are forced to live in abject poverty. In reality, Heller prophetically notes, the state will have to act with heavy doses of authoritarian socialism in order to maintain social order, however much conducted sotto voce so as to maintain the appearance of strict market justice. This will be done in a way that forecloses the route of parliamentary, political contestation that might democratically legitimate redistribution from the bottom-up. His conclusion is implicit but clear. Once the democratic route to social homogeneity is abandoned, the road to dictatorship is open.

\section{(b) Mortati: Constitution in the Material Sense and the Governing Function}

Costantino Mortati, a contemporary of Heller, was writing in a similar context of profound transformation of the State (in the Italian case, the consolidation of the new Fascist regime). Like Heller, Mortati was inspired by the coeval work on legal institutionalism. ${ }^{46}$ And Mortati was similarly troubled by the polarisation of positions illustrated by the debate between Kelsen and Schmitt, such juxtaposition detrimental to comprehending the intimate link between the formation and development of the constitution and societal order. ${ }^{47}$ But, unlike Heller, Mortati was inclined to adopt a realist interpretation of constitutional order.

42 Heller, 'Authoritarian Liberalism', above, 299.

43 ibid.

44 Polanyi, above, at 246.

45 The authoritarian liberal, Heller remarks, fights against the welfare state with one hand 'whilst subsiding large banks, large industry, and large agricultural enterprise' with the other. Above, 300 .

${ }^{46}$ For an introduction, in English, see I. Jennings, 'Institutional Theory', in Modern Theories of Law (Oxford University Press, 1933) 68-85. For a recent analysis of the tradition of institutionalism see M. Loughlin, Political Juriusprudence (Oxford University Press, 2017) chapters 6 \& 7; cf M. La Torre, Law as Institution (Springer, 2008).

47 Mortati has often been portrayed by Italian scholarship as a follower of Schmitt's constitutional thought. However, despite his admiration for the German constitutional lawyer, he made clear in several occasions his frustration for the deficit of concreteness and realism in Schmitt's work. For a comparison between the two authors see A. Catania, 'Mortati e Schmitt', in A. Catelani S. Labriola (eds), La costiturione materiale. Percorsi culturali e attualità di un'idea (Giuffré, 2001) 109-128. See, also, the remarks about Mortati’s rejection of 
Mortati's first seminal works aimed at capturing the constitutional reality of the new regimes which emerged after WWI. These works, denouncing the limits of a formalist conception of the constitution, were dedicated to the governing function, the discretion of administrative action and the constitution in the material sense. ${ }^{49} \mathrm{It}$ is not by chance that Mortati's reflections began with a discussion of the governing function, focused on the constitutional structure of the Fascist regime. It was a response to the manifest crisis of the liberal State, generated by the centrifugal pressure exerted by the masses upon the political system, which coincided with the extension of the suffrage and the parallel empowerment of trade unions. ${ }^{50}$ Mortati thus "discovers" the existence of a fourth constitutional function beyond the traditional three of the liberal model because he is looking for (a) an element of closure of the constitutional order which could not be found in liberal theories of the separation of powers and (b) a steering power which cannot be reduced to the executive, capable of cementing the political unity of the State. The governing function is described as essential, autonomous, supreme and distinct. ${ }^{51}$ It is the Ur-Funktion of the State legal order and, crucially, the one capable of moulding societal development.

In order to grasp the critical importance of governing, Mortati presents society as something that has to be organised, rather than a given. The governing function is the political drive behind this organisation of society. Society itself is grounded in two distinct but intertwined principles, differentiation and specification. Differentiation, which is immanent to all modern constitutions, ${ }^{52}$ is viewed by Mortati in terms of the basic distinction between those who rule and those who are ruled. ${ }^{33}$ This distinction highlights the central role played by authoritative command, but is also applied to societal organisation itself. ${ }^{54}$

Schmitt's existentialist account of the identity of the people in Loughlin, Foundations of Public Law, above 397.

${ }^{49}$ See respectively, C. Mortati, L'ordinamento del governo (Giuffré, 2000, or. ed. 1931); La volontà e la causa nell'atto amministrativo e nella legge (De Luca, 1935); La costiturione in senso materiale (Giuffré, 1998, or. ed. 1940). Available commentaries of Mortati's work in English are M. La Torre, 'The German Impact on Fascist Public Law: Costantino Mortati's Material Constitution' and G. Della Cananea, 'Mortati and the Science of Public Law', both in C. Joerges, N. Ghaleigh (eds), Darker Legacies of Law in Europe (Hart Publishing, 2003) 305-20 and 321-336.

${ }^{50}$ Santi Romano already diagnosed the crisis of the liberal form of the State in 1910, with a remarkable essay which served as the background to Mortati's early research: see Lo Stato moderno e la sua crisi (Pisa University Press, 2013, or. ed. 1910).

51 Mortati, L'ordinamento del governo, above 14-15.

${ }^{52}$ Mortati, La costiturione in senso materiale, above 56-61.

${ }^{53}$ Mortati explicitly rejected the dyad friend/enemy as foundational: see C. Mortati, 'Brevi note su costituzione e politica nel pensiero di Carl Schmitt' (1973) 2 Quaderni Fiorentini per la storia del pensiero giuridico 511, 518, where Mortati quotes J. Freund, L'essence du politique (Dalloz, 1965) 100 as an example of the primacy of the couple command/obedience (which he calls the dyad of political unity) over the couple friend/enemy (which Mortati defines as the couple of disintegration).

${ }^{54}$ Mortati believed that if the governing function were to be autonomous, distinct and supreme, it had to be entrusted to a specific supreme organ whose directives would be easily identifiable. In the same years, an alternative and insightful reflection on the governing 
Differentiation is essential for Mortati because the legal order takes shape only by making the organisation of society concrete, by defining specific roles and positions. Specification individuates the social and political groups that occupy those roles and positions. The artificial character of this process is realised only when certain groups become dominant, exercise the governing function, and in this way leave an imprint upon society. It occurs predominantly within the political system, and more precisely through organised (and mass-based) political parties. Mortati shares Heller's judgment about the importance of representative politics in the process of societal construction. Political unity cannot be achieved through abstractions. ${ }^{59}$ Society is 'the product of a differentiated integration of intersubjective relations', ${ }^{60}$ which can only be mediated by political parties.

The mediation of political subjects thus operates as an ordering factor of the material constitution, as the political forces construct unity out of differentiation and specification. What Mortati has in mind is a political party which is able to translate the life of the State into concrete State action, to the exclusion of conflicting conceptions. ${ }^{62}$ Mortati thus conceived the role of parties as strictly necessary to the consolidation of the political unity of the State. ${ }^{63} \mathrm{In}$ fact, only through the political mediation of parties ${ }^{64}$ can differentiation and specification be achieved in a way that is productive rather than destructive of unity. But in order to perform this function, political parties have to advance general political aims. ${ }^{65}$

In light of the previous remarks, one last point should be emphasised. Mortati believes that differentiation and specification as ordering processes cannot but be organised with a view to realise a concrete finality. This is the identifying moment of each and every form of State: it 'arises on the basis of assumptions that are the purpose and raison d'être of its founding and interpenetrate with its

function proposed to see it as spread across all three classic constitutional functions: see V. Crisafulli, Prima e dopo la costituzione (Editoriale Scientifica, 2015, or. ed. 1939).

${ }_{59}$ Mortati, La costiturione in senso materiale, above 138: 'the people taken in its generality, even if it develops a series of legal convictions concerning particular relationships, cannot supply the general principle of unification which serves to bring clashing interests to compromise and set the State moving towards a definite goal'.

${ }^{60}$ Mortati, 'Brevi note su costituzione e politica nel pensiero di Carl Schmitt', above 514.

${ }^{62}$ Mortati, La costiturione in senso materiale, above 71.

${ }^{63}$ It should be noted that this applies to the famous monograph published during the fascist regime and to the analysis of the republican political system as well. However, there is an important difference between Mortati's interpretation of the role of the single party during the fascist epoch and the fascist public lawyers: according to the latter, the party was an autonomous and sovereign institution, while according to Mortati the party is fundamentally an organ of the State. Cf. also, the difference with Schmitt's Movement, Party, State (Plutarch Press, 2001, or. ed. 1934).

${ }^{64}$ In his late works, Mortati seems to concede that political parties might not be the only bearers of the material constitution. Mortati made reference to the 'governing class' (as opposed to the political class), but never developed this point further: C. Mortati, 'Costituzione', in Una e indivisibile (Giuffré, 2008, or. ed. 1962) 162-163.

${ }^{65}$ General here means that these aims concern the whole society (or at least, a vast majority of its social relations). 
structure arranged so as to implement that foundation. It derives this purpose from sociological factors'.66

Differentiation and specification of the political forces that represent the ruling block and determine the political finality of the legal order are a critical element in explaining the material constitution. But, despite the central role of political forces, Mortati insists on the juristic nature of the processes behind the formation of the material constitution. This is a key point because in this way Mortati can avoid constitutional dualism, that is, a strict separation of facts and norms. To be able to take up the role of bearer of the material constitution requires that social or political groups are already organised, which means that they already have principles of organisation and concrete objectives. The material constitution can be described as an object of juristic knowledge because these objectives are introjected into law. This point cannot be underestimated: by making the political objectives juridically relevant, the governing function is harnessed to specific political aims which, at the same time, become primary sources of the legal order. ${ }^{67}$ In this way, Mortati describes the emergence of the material constitution as the condensation of a number of political groups around some fundamental political objectives with a view to their realisation with the support of legal institutions. ${ }^{68}$ This process is neither fully decisionist, because the selection of fundamental political objectives takes place in an environment already characterised by ordering factors (the political groups, in order to be effective, must have ordering principles) nor fully normativist, because the norms of the material constitution are marked by 'political law' (diritto politico), their content determined by the introjection of the political objectives into the norms themselves. ${ }^{69}$ Therefore, it is possible to identify the juridical core of the material constitution not in decisions or norms (as if they were two separate epistemic realms), but in normative facts, which are juridically cognizable. A normative fact is 'a fact which has in itself its own law and the guarantees of its persistence in the future'. ${ }^{70}$

This process could be identified with political hegemony. However, it should not be confused with the arbitrary or irrational exercise of power. Mortati is a constitutional realist, but not a legal realist: in his view, law cannot be reduced to a mere instrument in the hands of those who obtain political hegemony. ${ }^{76}$ The reason is the following: given that the material constitution is the result of

${ }^{66}$ Mortati, La volontà e la causa nell'atto amministrativo e nella legge, above 150.

${ }^{67}$ Mortati, Costiturione in senso materiale, above. 110.

${ }^{68}$ Cf C. Mortati, La costituente, in Raccolta di Scritti, vol. 1 (Giuffré, 1972, or. ed. 1946) 297.

${ }^{69}$ Mortati, Costiturione in senso materiale, above 106.

70 Mortati, La costituente, above 12. This is one of the doctrines where Mortati's legal institutionalism appears more evident.

${ }^{76}$ Mortati's material constitution has been compared to Gramsci's idea of hegemony. See, for example, G. Volpe, Il costiturionalismo del Novecento (Laterza, 2000) 122-127. While one can identify certain similarities (the role of the political party as the new prince being the most obvious one), it is on the instrumental use of law that Gramsci and Mortati come apart. Mortati would not concede that the law could ever be understood as a superstructure. 
processes of differentiation and specification which rely on complicated compromises around political objectives, not every use or manipulation of positive law is available. This is so for two reasons: first, the equilibrium obtained by differentiation and specification is based on a settled arrangement which is usually the end result of many compromises among the bearers of the material constitution; second, it is often the case that the hegemonic bloc introduces formal institutions as a guarantee of the material core of the constitution. ${ }^{77}$ Therefore, according to Mortati, the material constitution is never reducible to the registration of an elite's factual supremacy, but remains part of an order which usually also includes (and needs) the formal constitution.

\section{RENEWING THE MATERIAL CONSTITUTION}

To speak of the material constitution is not merely to insist, with a legal positivist such as Hans Kelsen, that the effectiveness of law, whilst not the same as its validity, is a condition of validity. ${ }^{88}$ That of course, is a truism. De jure authority depends on (and is conditioned by) de facto authority, as positivists as much as natural lawyers concede. But both positivist and naturalist traditions retain a methodology of separation of fact and norm that is inimical to understanding the constitution in practice, to tracking constitutional development in the interrelation of fact and norm. What, to adapt Kelsen's own terminology, are the conditions of effectiveness and how does law stand in relation to them? To this question, the positivist offers no answers. The positivist (as well as the naturalist) merely assumes effectiveness, or presupposes the existence of a 'standing constitutional tradition'. In an era where such traditions are looking increasingly precarious, and the effectiveness of law itself is in doubt, the question must be posed anew.

Kelsen's normativism and Schmitt's decisionism are dualistic theories that tend to self-negation by posing the initial point of view as absolute, either in the form of a logical norm (a 'transcendental presupposition') or an existential order. Heller and Mortati avoid this, and instead offer dynamic accounts, developing the interrelation of fact and norm, based in Heller's case on the democratic management of social homogeneity and in Mortati's case on the emergence of hegemonic forces capable of pursuing fundamental political aims.

Mortati lived long enough (until 1985) to see the first signs of crisis of the new material constitutional order and new type of State that had emerged in the postwar period. By the end of his academic career, he had come to recognise the

\footnotetext{
77 One example of post-WWII constitutionalism can illustrate this second point: constitutional courts can be seen as institutional guardians not only of the formal, but of the principles of the material constitution as well. One can see this logic at play in the case law concerning the doctrine of the so-called 'counter-limits'. For a reconstruction of this doctrine in the German context see J. Murkens, From Empire to Union (Oxford University Press, 2013) 203-206.

${ }^{88}$ See H. Kelsen, Introduction to the Problems of Legal Theory, translated by B.L. Paulson \& S.L. Paulson (Clarendon Press, 1992).
} 
limits of political parties in stabilising constitutional order. Their constituent moment was exhausted, incapable of overcoming the particularistic interests they represented. In the absence of proper mediation by political subjects, the principle of differentiation could no longer be effectively channelled. As a result Mortati began to make reference instead to the 'governing class'..$^{90}$ But this is not a minor or insignificant change of vocabulary. Whereas political parties were deemed to be constitutional organs, vague concepts like the governing class could not be identified as such. The upshot is that the only point of convergence on constitutional principles is provided by procedures upon which all interested parties can agree. Political activity is then reduced to a form of negotiation or deliberation. A procedural solution would bring us back to Kelsen (and in contemporary democratic theory, forward to Habermas's discourse theory). ${ }^{91}$ What is at stake, thus, is the primacy of the material constitution itself, that is, the primacy of the dynamic ordering of the constitution.

In the classical liberal constitutional State, form and function coincided. There was an intrinsic finality, the protection of individual freedom, and the techniques to guarantee it (protection of personal rights and the separation of powers). The form of the constitution contained its function as well. The transformation of the State in the $20^{\text {th }}$ century gave rise to a different typology. Each constitutional State develops its own set of fundamental aims, whether the Germany of the Weimar Republic, Spain's Franco regime or the constitutional order of the USSR. But these aims do not necessarily correspond to the State's constitutional structure. They will sometimes collide. The efficacy of form may be severed from the efficacy of function.

Constitutional ordering occurs both at the constituent moment of bootstrapping a new form of State into existence, and in the daily governing function required to maintain its authority. In conditions of growing complexity, the modern State will no longer be deemed merely a guardian or a neutral actor standing behind and apart from civil society. It is indeed unsurprising that theories of the material constitution were conceived during the interwar breakdown of liberal constitutionalism, the emergence of political authoritarianism, and the consolidation of the fascist corporatist State and then of the new Welfare State that emerged after World War II. In these circumstances the material order of the state was more visibly seen.

Despite their significant contributions, Heller's and Mortati's efforts, however, remain insufficiently materialist. While the statist and institutionalist bases of their constitutional doctrines are resonant because they attempt to integrate the relation between societal formation, institutional power, and constitutional order, there is a formalist remainder. According to Mortati, the material core is in the end specified by the hegemony of the ruling political block and its fundamental political aims. According to Heller, it is ultimately determined

${ }_{90}$ Mortati, 'Costituzione', above 162.

91 See J. Habermas, Between Facts and Norms: Contributions to a Discourse Theory of Law and Democracy (MIT Press, 1996). 
by the individual conscience as an ethical question of the common good. The core of the material constitution, its teleological unity, is left to the vagaries of sheer political circumstance or, at best, the interiority of ethical conscience. In both cases, social relations are converted into political considerations in order to be integrated as constitutional. They are not properly addressed as materially productive of constitutional order in their own right.

It is the task now therefore to provide a fuller theory of the material constitution, specifically an account of the substantial content of its ordering forces. 92

\section{THE FOUR ORDERING FORCES OF THE MATERIAL CONSTITUTION}

The conditions of constitutional formation and durability include political economy, political culture, social relations, religion, as well as geopolitical factors, international relations and imperial forms of domination. It is not just that the development of modern constitutions is shaped by these factors from the outside, as it were, as mere irritants to an already established order. It is that they combine to constitute order itself and to condition constitutional development through processes of re-ordering (and of disordering).

These factors can be integrated into constitutional enquiry by placing their relation with the constitution at the centre of analysis. Taking this approach means, for constitutional scholars, to take as matters of juristic knowledge, geopolitical, political, and social concepts which had been previously been delegated or relegated - to other disciplines, such as sociology, international relations, and political theory. Material conditions and relations are thus both constituted (by law and politics) and constitutive (of law and politics). The dynamic interactions among these elements are intrinsic to constitutional ordering.

Since there is always an internal relation between constitutional order and society, the constitution is conceived as a feature of political and social power. But power here is neither an insurgent mass nor a mere abstract relation. The formation, subsistence and reproduction of society always already entails constitutional ordering. In that sense constitutional power is always already constituted as well as constituting power, as Hans Lindahl has carefully theoretically reconstructed. ${ }^{33}$ But how is it ordered? And why might order turn to disorder? In the next section we consider how to organise and conceptualise the process of constitutional ordering by offering four inter-linked building blocks of analysis.

92 Traces of this material analysis are scattered in Mortati's reading of the labourist principle lying at the core of the Italian republican constitution (art. 1): C. Mortati, Il lavoro nella costituzione (Giuffré, 2005, or. ed 1950).

93 See H. Lindahl, 'Constituent Power and Reflexive Identity: Towards an Ontology of Collective Selfhood', in M. Loughlin, N. Walker (eds), The Paradox of Constitutionalism (Oxford University Press, 2007) 9-24. 
The first force of constitutional ordering is the production and reproduction of political unity. A political unity gives sense to a constitution, trivially to enable us to speak, as we do, of the German Constitution, the United States Constitution or the Egyptian Constitution. The constitution exists as a political unity, not as an abstract set of norms. Even here, however, we should notice immediately that ambiguities are raised in relation to the historical context. Are we speaking of the Basic Law of the Federal Republic of Germany? Before or after reunification? Before or after the OMT decision of the Bundesverfassungsgerricht? We might of course be offering a snapshot, speaking of a momentary constitutional order, but this will not be very revealing as a matter of constitutional theory. The constitutional order is always a process of becoming.

In a standard narrative, the rupture on which political unity is built is immaterial: it is the autonomy - and primacy - of the political from the theological domain that opens the space for modern constitutional ordering. ${ }^{94}$ This transition is captured by Marcel Gauchet's 'secularization thesis', which characterises modernity as a process of religious disenchantment, signalled by the secularization of the grounds of political authority. ${ }^{95}$ It is the symbolic transformation of that play the lead role in commencing and advancing the process of modern constitutional ordering.

But what are the material conditions of this rupture and the political unity it inaugurates? The formation of political unity requires a material process of political integration (or disintegration and re-integration as the case may be) of a collectivity. A constitutional order, in other words, represents a certain conception of political space (which, in the political form of the modern State, is conceived as territory $)^{97}$ and often has a clearly marked origin in time.

Political unity takes specific forms in particular historical epochs and geographical spaces. It is part of constitutional analysis to track this, to consider what conditions its development and what are the constitutional implications of a particular form. Whether the political unity is obtained through a nation-state, a federal state, a multinational federation, an inter-state confederation, a supranational union or imperial domination, reflects a particular path of institutional and societal development and therefore a particular path of constitutional ordering. Conversely, the formal constitution and its interpretation by official bodies can have a significant and even decisive impact on the path taken towards political unity.

Yet despite the variations and the distinct types of political unity that emerge in this process of constitutional ordering, the modern European nation-state

${ }^{94}$ See M. Loughlin, Foundations of Public Law (Oxford University Press, 2010).

${ }^{5}$ M. Gauchet, The Disenchantment of the World: A Political History of Religion (Diane Publishing, 2001).

${ }^{97}$ For example, cf H. Lefevbre, The Production of Space (Blackwell, 1991); on the material limits of Lefevbre's reconstruction see N. Brenner, S. Elden, 'Henri Lefevbre on State, Space, Territory' 4 (2009) International Political Sociology 353-377. 
remains paradigmatic (at least in Europe). Its internal relation to the material constitution therefore deserves particular attention.

The ideal-type of a nation-state is consolidated as a political unity through the establishment of a bounded community of belonging. In an influential account, it is constructed as a shared community of fate based on the imagined belonging to a nation. ${ }^{101}$ Attachment to a constitution can itself play a significant symbolic role in this process of collective identity formation, captured in the idea of constitutional patriotism. ${ }^{102}$ Collective identity is thus understood as politically constructed. But shared identity can also be presented as a presupposition of constitutionalism, and hence as a vector of or even an obstacle to constitutional re-ordering. ${ }^{103}$

The modern nation-state is consolidated as a constitutional order by becoming a politically sovereign entity, in a two-fold manner, captured by what Carl Schmitt termed the Jus Publicum Europeaum. ${ }^{104}$ Internally, the European nationstate acquires the monopoly of legitimate force over the course of the 'long 19th century' (from the French Revolution to the First World War). Externally, it is recognised as the only legitimate subject of international relations, with the right to decide on matters of war and peace, subject to conventions regarding civilized warfare.

But neither bounded community nor political sovereignty accounts for the material dynamic of constitutional ordering. To pursue this further, we can begin with Schmitt's retrieval of the term 'nomos' from the original Greek meaning, as a territorial unity of law and space. The meaning of classical state sovereignty in the Euro-centric tradition is, according to Schmitt, a concrete order based on land appropriation and claim to radical title overseas. This material grounding of political unity on an initial appropriation of land brings it into contact with an established as well as critical tradition in political economy, which presents it as setting in train and conditioning capitalist economic development: Adam Smith's 'previous accumulation', Marx's 'original' or 'primitive accumulation', Max Weber's 'political capitalism'. Hannah Arendt, following Rosa Luxemburg, describing the imperialism of the late $19^{\text {th }}$ century, calls it 'simple robbery'. ${ }^{106}$

But political unity then looks to stand on much less firm ground than Schmitt's nomos. It emerges on the shifting sands of material development, in relation to production and distribution (and not only taking) of land as well to the material organisation of (unequal) social relations based on labour and money. Luxemburg had directly recalled the added significance of nomos as nahme in relation to modern imperialism, picked up in her analysis of imperial Landnahme not only as an act of 'land-grabbing', but also as a process of capitalist market

${ }^{101}$ See B. Anderson, Imagined Communities: Reflections on the Origin and Spread of Nationalism (Verso, 1983).

102 See e.g. J-W. Muller, 'A General Theory of Constitutional Patriotism' (2008) 6 International Journal of Constitutional Law 72 - 95.

103 See e.g. D. Grimm, 'Does Europe Need a Constitution?' (1995) European Law Journal 282.

${ }^{104}$ See C. Schmitt, The Nomos of the Earth (Telos Press, 2006).

106 See H. Arendt, Origins of Totalitarianism (Harcourt, 1968), 148. 
expansion. ${ }^{107}$ The focus merely on an initial land grab occludes the material development of this early modern nomos. As David Harvey more recently notes, the modern state is not only founded on an initial 'grab' but its class character (relations of domination) is maintained through reiterated processes of 'accumulation by dispossession'. This occurs not only through force and fraud, but also through formal measures of privatisation and austerity, managing the relation between private and public debt. 108

The formation of political unity thus occurs in relation not (only) to the symbolic moment of religious disenchantment, nor (only) to a bounded community based on the concrete act of territorial appropriation, but to the political and economic organization and re-organisation of social relations across time and space.

From this viewpoint, the process of constitutional ordering is internally related to the transformation of the state from a feudal to a capitalist and later imperial organization of power. It is dependent upon and in tension with unequal relations - relations of domination - between, for example, capital and labour, or core and periphery. Constitutional ordering then looks like a fraught, contingent and uneven historical dynamic based on material factors that are reproduced politically, not only since the state has to provide for security and welfare but because the claims to popular sovereignty, national community and imperial domination (as well as class-based and anti-imperialist counter-claims to emancipation or self-determination) are themselves features of material demands for expansion or inclusion of the demos.

The territorial and communitarian logic of political unity and the capitalist logic of domestic and imperialist market expansion exist in a tense relationship. ${ }^{109}$ Political unity itself is threatened by the perception that constitutional ordering occurs on the basis of brute economic domination, whether of a dominant domestic ruling class, a dominant state within a federation, or an imperial power. For constitutional ordering to produce a relatively stable political unity, such as a nation-state or a supranational union, and not merely an order of economic domination, such as the executive committee of the bourgeoisie or a hegemonic bloc of creditor states, the notional separation of political and economic power is required.

The internal relationship between the formation of political unity and economic domination is thus significant in that the modern nation state is typically conceptualised in constitutional theory as a political form in which authority does

${ }^{107}$ Schmitt omits discussion of Luxemburg's updating of Marxism for the imperial age; he does however, briefly address Marx's idea of original appropriation in Nomos of the Earth, 333- 334, adding that, 'if the essence of imperialism lies in the precedence of appropriation before distribution and production, then a doctrine such as expropriation of the expropriators is obviously the strongest imperialism, because it is the most modern' 334 .

108 D. Harvey, The New Imperialism (Oxford University Press, 2003); M. Blyth, Austerity: The History of a Dangerous Idea (Oxford University Press, 2013).

${ }^{109}$ See e.g. W. Streeck, 'Taking Capitalism Seriously: Towards an Institutional Approach to Contemporary Political Economy' (2011) Socio-Economic Review 137 - 167. 
not rest on the explicit fusion of political and economic power: it is the relative autonomy of the political from the economic that sustains modern constitutional authority, distinguishing it from prior political forms, medieval as well as ancient. ${ }^{110}$ But if the modern state represents not only a formal (or brute) appropriation of land, but - as dynamic material ordering - a transformation of social and geopolitical relations through the commodification of land, labour and money based on forms of economic domination, the relation between political unity and material inequalities will be continually raising tensions and conflicts. ${ }^{111}$

The formation of modern statehood is internally related to a dynamic of formal equality (political unity) and material inequality (within a relatively autonomous economic sphere). It requires a relatively autonomous mode of political authority as well as the means of ensuring the flow of capital accumulation through the structures of the bourgeois Rechtsstaat, and other forms (and informal modes) of geo-political domination and market expansion. ${ }^{112}$ Political unity requires and builds bounded community and political sovereignty, but is both made possible and threatened by the material relations of inequality and domination that pervade civil society. The process of attaining and maintaining political unity is thus unstable, and this instability is manifested in the material order itself.

\section{b) INSTITUTIONS}

This outline trace of the dynamic formation of political unity does not capture the full substratum of the material order. The formation of political unity, and of a constitution itself, depends on the work of institutions, including but not limited to formal governmental branches such as courts, parliaments, executives, administrations, central banks; it also depends on non-governmental, informal, societal and cultural institutions, such as family, language, property, trade unions, myths and symbols. These have a unifying role and exercise an ordering force but evidently enjoy some autonomy from the logic of political unity. ${ }^{113}$

Institutions are the 'objects' which comprise the material constitution (in Aristotelian terms, its material cause). They are produced through social interactions and develop their own institutional normativity, in the manner of customs or conventions. Their existence is crucial for the formation of the constitutional order, but they may lead to fragmentation and instability. Hence, institutions perform an ordering function only when they can be combined in a

${ }^{110}$ Cf. E. Wood, From Lords to Citizens: A Social History of Western Political Thought (Verso, 2011).

111 See R. Luxemburg, The Accumulation of Capital: A Contribution to an Economic Explanation of Imperialism (Routledge, 2003 (1913)). These are the three 'fictitious commodities'; commodification of which Polanyi thought leads to a double-movement of social reaction or re-embedding, potentially destabilising the constitutional order. See, K. Polanyi, The Great Transformation (Beacon Press, 1944) ch. 6.

112 See K. Polanyi The Great Transformation: The Political and Economic Origins of Our Time, above chapters 4 \& 5 .

113 On the idea that institutions have their own internal principles because they are 'social organizations', see the seminal work by S. Romano, The Legal Order (Routledge, 2017) 19. 
way that is compatible with the concrete form of political unity. The combination of institutions in support of the constitutional order is part of the art of governing.

Construction of the social order is an artificial and selective political activity. There is no natural connection between a given political community and the institutions that the legal order of that community protects and advances. It is partially the role of political activity to carry out a selective job and identify institutions that are conducive to a relatively stable order. ${ }^{117}$ Such selection is to some extent context-specific and, of course, never neutral. ${ }^{118}$ It may require the support of processes of socialisation and daily learning practices. The awareness of this stratified conception of the material order of society emerges clearly in Heller's work, where, describing one of the five meanings of the constitution (the material constitution in the wide sense), he notes that fundamental ethical principles are made intelligible to both the governing and the governed not by a basic norm, but, among other things, 'by tradition, political expediency, situations of power and the legal culture'. ${ }^{119}$ To perform this consolidating function, there must be political and legal institutions which take it upon themselves to protect and foster social institutions and their substantive identity.

These processes should not be viewed as isolated events. Constitutional ordering, as noted above, is a dynamic process of becoming and this means, from a material perspective, the possibility of adaptation (within certain limits) to challenges and internal conflicts. ${ }^{122}$ Because of the potential integration of previously excluded figures, conflicts can nurture the material constitution by strengthening the institutions involved in their management or deferral. Institutions, including formal constitutional ones, rarely resolve conflicts as such, but they might prevent them from degenerating into outright hostility or political and societal collapse, acting as pressure valves for conflictual energies to be spent. And because there is always room for new interpretations of an institution's normativity, and for new institutions to emerge, the material constitution must remain flexible and dynamic if it is to negotatiate the challenge of integration.

Institutions are fragile achievements. They come under pressure both from above, when for example, they come into conflict with forces of political unification or material economic expansion, and from below, when social relations

117 Later in his career, Schmitt will emphasise this aspect of concrete order thinking, in particular in his On the Three Types of Juristic Thought (Praeger, 2004). For a reconstruction of this phase of Schmitt's thought, see M. Croce and A. Salvatore, The Legal Theory of Carl Schmitt (Routledge, 2013) 30-45.

118 Note that Mortati envisaged a way to strengthen the link between political institutions and society by hinting that judges and administrative agencies should not operate in a fully neutral way because 'the activities of the organs themselves [...] must be arranged in such a way as to fit the ends to which they are directed: which requires of those persons who have to carry out the activity itself not the capacity to be impersonal interpreters, but conformity with a type that is harmonious with a given ideology': Volontà e causa nell'atto amministrativo, above 126 (italics added). Later, Mortati maintained the idea that institutions are not acting in a neutral sphere, but dropped the reference to the 'type' of person.

${ }^{119}$ H. Heller, 'Nature and Function of the State' (1996) 8 Cardozo Law Review 1213.

${ }^{122}$ For further reflection on this key point, see section 5, below. 
emerge in a manner which threatens their continuing stability. Trust in institutions might then be eroded, even fatally, and the need arise for their reconstruction.

The story of constitutional law in Europe in the second half of the twentieth century is, for example, one of extraordinary institution re-building on the basis of new forms of political accountability, frequently non-majoritarian or technocratic. ${ }^{123}$ From the pre-eminence of constitutional courts to the more recent rise of independent central banks, this reflects a distinct set of beliefs about the institutional mediation of the governing relationship, beliefs which were in part formed out of reaction to the breakdown of liberal democratic institutions in the interwar period. ${ }^{124}$ This process of institution-building continues at the supranational and international level, through the project of European integration and the European Convention on Human Rights. As institutions acquire a certain life of their own, however, most notably in the case of the EU, their social disembeddedness poses distinct problems of constitutional legitimacy. With the proliferation of institutions come added layers of complexity as well as increasing points of conflict, at the interface between domestic and supranational institutions (most evidently between judicial authorities at national and European level) but also between clashing logics of rationality, such as between legality and market rationality, competition and solidarity, and between opposing political and social forces. ${ }^{125}$

Heterogeneous social relations and material conflicts condition the institutions that order the process of constitutional development. Since institutions might mediate conflicts between state and society but do not finally resolve them, we need to turn to a further ordering force, that of the 'horizontal' social relations that pertain between the individuals who constitute a political unity and who comprise the instituting power of the society.

Institutions themselves are based on a relatively autonomous instituting power, which erupts out of society and the social imaginary. ${ }^{126}$ The instituting power reflects not only social conflict but also forms of co-operation and solidarity. These twin drivers of social reproduction must be kept in view.

\section{c) SOCIAL RELATIONS}

The most basic material out of which a constitution is formed lies below the layer of institutions. It consists in subjective social interaction as well as social conflict. This is conditioned (sometimes tempered, as well as occasionally inflamed) by movements of solidarity as well as by competition. Social conflict and interaction is softened, concealed, maybe even displaced by the unifying function of

\footnotetext{
${ }^{123}$ See e.g. J.-W. Müller, Contesting Democracy: Political Ideas in Twentieth Century Europe (Princeton University Press, 2011)

124 See e.g. M. Wilkinson, 'The Reconstitution of Postwar Europe: Liberal Excesses, Democratic Deficiencies' in M. Dowdle and M. Wilkinson (eds.) Constitutionalism Beyond Liberalism (Cambridge University Press, 2017) 38-79.

125 See e.g. The OMT saga, Special Issue of the German Law Journal, vol. 15, n 2 (2015).

${ }^{126}$ See C. Castoriadis, The Imaginary Institution of Society, tr, K. Blamey (MIT Press, 1997).
} 
institutions and the political unity of the state itself, but not (perhaps never), fully or finally resolved.

The extent to which social relations (and in turn the institutions and political unity they constitute) are conditioned by specific forms of class consciousness and class domination - where class need not be determined by ownership of the means of production as understood in orthodox Marxism - remains a live question. But it is an important advantage of our approach, over a purely political jurisprudence (or a formal constitutionalism), that the relationship and the distance (or disconnect) between rulers and ruled and between the ruled themselves is not represented as purely formal or hierarchical. In a society which considers itself democratic, or in some sense as self-governing, the idea of a gap between rulers and ruled is itself antithetical to constitutional ordering, at least to its self-image as a democratic society. This is not to say there can be a pure identity between rulers and ruled. It is to say that the relation between rulers and ruled is a material and dynamic one that takes a certain trajectory in a democratic and capitalist society, because of the aspiration to the inter-changeability of rulers and ruled based on some notion of political equality on the one hand, and the market economy as a driver of social inequality and domination on the other. ${ }^{127}$

Constitutional actors (subjects) must not therefore be reduced to the status of already constituted or abstract objects (or institutions). Instead, constitutional study must focus equally on the processes of 'subjectivation', emphasising the formation of collective political actors and their contribution to constitutional change. This is also a question of identification: does the individual conceive of himself or herself, for example, predominantly as a part of a particular class, nation, or ethnicity, as a citizen, entrepreneur or a consumer? Or in what combination?

Constitutional lawyers can return to old insights from sociologically-sensitive studies of the constitution in order to integrate processes of political subjectivation into the analysis. The substantive production and reproduction of material order is the outcome of a series of social, political and geopolitical conflicts through which collective subjectivities are forged. Collective subjects provide the impetus for the material dynamic of political formation and institutional development. We need, then, to shift the constitutional focus from the abstract individual (or institution) back to these processes of subjectivation, as well as their potential for inclusion and exclusion.

To restate a well-known insight of Machiavelli, if the emergence of a new material constitution is possible only through the political action of the prince, or equivalent (in Gramsci's version, the political party), ${ }^{128}$ this depends on processes of selective subjectivation and must be sustained by a series of organised political subjects. Contrary to Heller and Mortati, political here should be read lato sensu and not in any way limited to political parties or otherwise already institutionalised

${ }^{127}$ See W. Streeck, Buying Time: On the Delayed Crisis of Democratic Capitalism (Verso, 2014)

128 A. Gramsci, Selection from the Prison Notebooks (International Publishers, 1971) 253. 
forms. It should include informal groups and social movements, including antisystemic and disordering social forces (e.g. worker's movements, women's movements, anti-colonial movements).

Although study of political economy is essential for understanding the material formation and reproduction of society (its metaphorical 'backbone'), the structure and content of the material constitution is not economically determined. Its emergence is clearly intertwined with the concrete organisation of the political economy, but the study of the material constitution cannot be reduced to the study of the underlying economic base. ${ }^{129}$ Or, to put it differently, the economic base must not be presented as over-determining the material constitution; rather they are inter-related. Political economy stands upon existing forms of order and its trajectory is advanced by a (constrained) series of political actions, including those represented through the formation of political unity. Political subjects are thus essential in the formation and then preservation of a particular political economy, as well as in fomenting change through putting pressure on reforming the political-economic structure through movements of solidarity or competition.

If social relations become too materially heterogeneous, through the rise in socio-economic inequality, constitutional ordering itself may become difficult particularly if representative of a gulf between rulers and ruled. As the underlying social relations become fraught, instability or even revolt beckons. Heller so presciently suggested this in late Weimar as a matter of constitutional disordering, and it is a theme that has returned to prominence since the financial crisis. ${ }^{130}$

This reveals a point of divergence from the dominant sociological approach to constitutionalism, which endorses or implies a communicative rationality or even ideal consensus. In these systemic approaches, only communicative exchanges in accordance with the relevant code are registered. ${ }^{131}$ The internal relation between constitution and society is conceived in utterly irenic terms, except for the exceptional cases when a system is going to 'hit the bottom'. ${ }^{132}$ But neither ordering, nor, significantly, disordering constitutional forces can be accounted for in such terms. It leaves insufficient constitutional room for political subjectivation, societal conflicts, social movements and anti-systemic forces (whose aim is to change the constitution is an irregular manner or in terms that would affect its substantive identity). Conflict is endemic to the process of constitutional ordering, not peripheral.

\footnotetext{
129 An example of this form of reductivism is C. Beard, An Economic Interpretation of the Constitution of the United States (MacMillan, 1913).

130 This seems largely due to the influence of Thomas Piketty's work on inequality, Capital in the Twenty-First Century (Cambridge Mass, Harvard University Press, 2014). See e.g. D. Singh

Grewal, 'The Law of Capital' (2014) Harvard Law Review 626 - 667

${ }^{131}$ See especially G. Teubner, Constitutional Fragments (Oxford University Press, 2012); for an overview see C. Thornhill, P. Blokker (eds), Sociological Constitutionalism (Cambridge University Press, 2017).

132 For a critique of this argument see E. Christodoulidis, 'On the Politics of Societal Constitutionalism’ (2013) 20 Indiana Journal of Global Studies 629.
} 
The political, subjective and conflictual dimension of the material constitution suggests an affinity with the Marxist tradition. This has recently been revitalised in constitutional theory in the work of Antonio Negri, and the view proposed here shares something with it. ${ }^{133}$ Negri's materialist understanding of the constitution permits a focus on movement rather than merely origins and is able to explain material constitutional development. For Negri, the material constitution refers to 'the continuous formation and re-formation of the composition of social forces'. ${ }^{134}$ This movement is determined through class struggles, which are consubstantial with processes of collective subjectivation the construction and formation of collective subjects. The material constitution thus evolves within spatially delimited coordinates (the factory, then society itself) as collective subjects are formed. This aspect of collective agency avoids the reduction of the material constitution to what might be called 'structure without subjects', or 'natural-social' relations of production (which include exchange, law, culture, ideological practices). ${ }^{135}$ The view of the constitution as the imposition upon society of an order by an already formed elite is rightly rejected. ${ }^{136}$

Yet Negri grants insufficient space to political activity intended as something relatively autonomous from societal struggle and, in later versions of his theory, ends up undermining the productive role of class conflict itself. It is no coincidence that his collective subject becomes the multitude (counterpart to an equally nebulous and unitary Empire), and that the only thing missing for the reconstitution of the material order is for this multitude to become conscious of its status as living labour, that is, as the engine of societal reproduction.

In our account, on the contrary, the struggles which animate the material constitution are conducted by a plurality of subjects whose positions are conditioned but not determined by already established relations of production. Subjectivity does not stem from social relations of production and re-production in a completely direct and spontaneous way. It is mediated through political organisation, political institutions and political strategies. Economic and social forces must not be presented as over-determining the material constitution precisely because their role in shaping the constitutional order has to be understood in relational terms and not just as a top-down exercise of ruling power (or a bottom-up mirror image). Economic and social forces do actively order certain aspects of the material constitution, but their composition and their relation are also constantly subject to tensions and conflicts generated by other forces, including political unity, institutions and fundamental political objectives.

\footnotetext{
133 See especially, Insurgencies (Indiana University Press, 1999) ch 1. Negri compares his approach to Teubner's in 'Law, Property and New Horizons' (2010) 21 Finnish Yearbook of International Law 1.

134 A. Negri and M. Hardt, Empire (Harvard University Press, 2000) xiv.

135 This is a topos of Italian workerism, as aptly illustrated in one of the founding texts: M. Tronti, Operai e capitale (Derive \& Approdi, 2013, or. ed. 1966).

136 A. Negri, Labor of Dionysus (University of Minnesota Press, 1994) 63.
} 
There is a final force that conditions the material constitutional order, and may even hold it together in spite of social conflict, political disunity and institutional weakness. This is captured by a material telos (or set of telor). Constitutional subjects and institutions project certain basic or fundamental political objectives, or even a future 'finality' of aim, and this of course forecloses or elides others. Again, the formal constitution stands in relation to these objectives, sometimes in tension with them, sometimes in harmony.

It is essential to bear in mind that the three previous ordering forces contain their own internal ordering logic. However, they have to be understood as part of a constellation whose boundaries are ultimately drawn by the objectives of the material constitution. Political unity, institutions and development of social relations according to specific patterns are not simply achievements in and for themselves. Their formation and specification is driven by the teleological orientation dictated by fundamental objectives. Of course, this is not a smooth nor unidirectional process. The trajectory dictated by one ordering force of the material constitution will sometimes conflict with the trajectory of another. The constitution will therefore evolve according to the complex interplay of political, institutional and social change. It will also evolve in relation to the trajectory laid down in the formal constitution and its interpretation by official bodies and institutions. At the same time, the formation of political unity, the consolidation of institutions and the development of social relations are constrained by fundamental objectives in the sense that these limit their margin of manoeuvre.

The set of explicit and implicit constitutional aims and objectives reflects the composition of dominant social, political and geo-political forces around it. But it also acts as a catalyst. This perspective offers an alternative to classic constitutional doctrines, which, in accordance with much modern political philosophy, lay emphasis on the origin of the constitution, as if it contains within itself the energy for the creation and the further development of the constitutional order. This origin then appears as external, both to society and to the constitution. As in the case of a mechanical device, the original act would set in motion the constitution from the outside, acting as an external referent.

Social contract thinking, which influences a great deal of constitutional theory in the liberal and republican traditions, thus poses the creation of society and the conditions of constitutional order from an external perspective, that is, from a prepolitical, hypothetical or 'natural' condition. The social relations that pertain at the time of the so-called origin (whether state of nature or original position) are then concealed, nullified by virtue of a thought experiment but one that acts as a distorting lens because it de-politicises existing material conditions and social relations. Once translated into constitutional law, it also legitimises the displacement of matters from the ordinary political and social domains of 
contestation. ${ }^{137}$ In other words, the material constitution is often entirely (and deliberately) concealed from view.

Decisionism, despite being radically different to social contract in its formal outlook, assumes a similar starting point: the origin of the legal order, its 'big bang', containing the seeds for its further development, lies in a position outside of the order itself. The constituent power is conceived as causa incausata, creating a new order out of nothing, a quality which can return through the state of exception. The origin can then also offer a conservative position, defending the constitution reactively against political and social change or against agitation for such change.

Our study of the material constitution takes a different approach. Societal formation is always already political; the constitution does not and cannot come out of nothing or from a state of nature. What makes societal formation possible in the first place, within a determinate space and through the mediation of already existing institutions, is the convergence of certain political and social forces upon a series of basic political aims and a capacity to affirm them. The state of exception then exists within the constitution understood as a material order.

Through political association, different social forces will tend to commit themselves to pursue distinct aims for different reasons and on the basis of distinct interests. Through converging upon these aims, hegemonic forces are able impress a particular trajectory upon the material constitution. The conditions which make this possible are captured by Poulantzas's relational conception of political power. Poulantzas argued that the material constitution is formed by the 'condensation of social forces' around a set of political aims. ${ }^{138} \mathrm{~A}$ version of his research question should guide the study of the material constitution: 'why have liberal democracies decided to give themselves these particular political constitutions and not others?' And how do they change over time? These forces may be informal as well as formal, they could be predominantly domestic, but they could also be formed by a hegemonic bloc within a federation, or geo-political domination.

At the same time, the teleology of the material constitution, by developing according to its own (relatively autonomous) logic, moulds the identity of the hegemonic forces over time. The trajectory of the material constitution is thus conditioned by the objectification of its aims: such an objectification then imposes limits on the manner in which to achieve them. ${ }^{139}$ In other words, the hegemonic forces which support the material constitution are not entirely free to change course, without limits or constraints. Moreover, the formulation and pursuit of fundamental political aims might generate unpredictable consequences, contradictions or paradoxes in the unfolding of the material constitution. This is to say that in the actual pursuit of common political aims, unforeseen spaces might

${ }^{137}$ See S. Wolin, 'The Liberal/Democratic Divide: on Rawl's Political Liberalism' (1996) 24 Political Theory $97-119$.

138 Poulantzas, State, Power, Socialism, above at 11.

139 R. Cover, 'Nomos and Narrative' (1983) 97 Harvard Law Review 4, 44-46. 
open up for new subjectivities or changes in alliances, and with potentially disruptive effects.

The level of intensity of overall social and institutional support is an important indication of the strength of a material constitution. The stronger the support for the political aims (or even finality) of a regime, the more solid is its material constitution. Without such a trajectory, the material constitution will struggle to hold together, particularly when aims directly conflict and the space of contestation is closed down.

It is important to note that there will not necessarily be convergence on these aims. Divergence will ensue and existential struggle will also sometimes occur. In fact, as suggested above, in the context of political and geo-political capitalist dynamics based on competition, class conflict, and imperial domination, as well opposing social dynamics based on solidarity, cooperation and emancipation, divergence is inevitable. At certain conjunctural moments, where the oppositional forces combine to present an existential or constitutional crisis, with no overall hegemonic force prevailing, there will be greater fluidity of possibilities, and new trajectories will likely emerge, along with new hegemonic forces.

The notion of a constitutional teleology is an old one. As Aristotle puts it in the Politics, the 'constitution... reveals the aim of the city-state'. ${ }^{140}$ This may seem enigmatic but at a minimum, of course, the implicit aim is the survival of the state, polity, or project of political unity. But frequently, and increasingly, formal constitutions themselves present more content-specific aims or explicitly announce a telos (or set of telor). This is the case with many modern constitutions, particularly those instituted in Western Europe in the aftermath of the Second World War, which promote particular, if still rather underdetermined values, such as democracy, federalism, human rights, or social welfare. ${ }^{141}$

This focus on particular political aims sheds a light on the nature of the art of governing, which as noted by Mortati, cannot be reduced to the other three classic constitutional functions. But the notion of functions here must not mislead. The teleological dimension of the art of governing is shaped by political action rather than sheer functionality. This is not a pedantic distinction because it carries with it important consequences for understanding the process of constitutional ordering. It might be possible for one particular institution in a given constitutional order to have the power and the responsibility to steer the governing function toward the pursuit of certain fundamental political aims, but this is unlikely. With the growing complexity of constitutional structures, it has become increasingly difficult to identify the governing function in one single aim or single institution. In fact, since the finality of governing a society is not limited to its survival as such but includes the realisation or preservation of specific aims, it is more accurate to seek the teleology of the material constitution across the institutional spectrum and even beyond into the dimension of social relations. In brief, the teleology of the

140 Aristotles, Politics [1.1.1252a1-7], [IV.1.1289a17-18].

${ }^{141}$ For a reconstruction of this moment see A. Somek, The Cosmopolitan Constitution (Oxford University Press, 2014) chapters 4 \& 5. 
constitution is material rather than formal, relating to all the ordering forces of the constitution.

\section{THE MATERIAL AND THE FORMAL CONSTITUTION}

Having outlined the ordering forces of the material constitution, we can relate it to the 'formal' constitution - the constitutional texts and unwritten conventions as interpreted by official bodies. If the formal constitution is the sum of all constitutional norms and principles that drive the regulation of political and social interactions (constituting the 'laws of law-making'), this stands in relation to the material constitution, but not merely as a relation of form to function or form to content. An analysis of the function and content of constitutional norms is of course a first and important step in any constitutional enquiry. Constitutions do not only establish and regulate a formal process of law-making; they invariably protect certain material interests, from freedom of speech to balanced budgets. This tells us something about the content of the constitution, at the very least as a set of aspirational goals or political and social objectives.

But the material constitution is not merely the 'content' of the formal constitution or the totality of formal constitutional norms (even extending this to include informal norms and principles); neither does it compete with, substitute for or stand in antagonistic relation to the validity of the formal constitution. It does not determine the outcome of political action nor the result of judicial adjudication. That might contingently appear to be the case, particularly in episodes of political crisis, when positive legal norms are bypassed or the letter of the law is overlooked, pushed by clearly identifiable material forces or hedged in by material constraints. But critical or conjunctural periods, where material forces push in antagonistic directions and open up alternative paths for constitutional change, also reveal the relative indeterminacy of the material order.

Rather, the formal constitution is a feature, an instance, of the material constitution, ${ }^{142}$ part of the wider constitutional order. Without a corresponding material constitution, without political and social traction, a formal constitution remains a 'dead letter', a list of wishful auspices or even a 'sham'. In that case, form and function may depart so far as to call into question the very discourse of constitution and of constitutionalism. But, to adopt the language of $19^{\text {th }}$ century jurist Ferdinand Lassalle, the distance between the juridical [or formal] constitution' and a 'real constitution' ('the actual relationships of power in a country') must be grasped as a matter of constitutional law and constitutional theory. ${ }^{143}$ And it is important to note that the distance exists in liberal democratic as much as non-liberal or non-democratic regimes. All constitutions, it might be said, are relatively sham, given the distance between their formal aspirations and their lived reality.

142 C. Mortati, La costiturione in senso materiale, above 138.

${ }^{143}$ F. Lassalle, 'Uber Verfassungswesen' in 2 Gesammalte Reden Und Schriften 38 (Cassirer ed., 1920). 
The 'distance' between constitutional form and constitutional material is of course a matter of degree and admits of little analytical precision. But the metaphor of gap or distance is in fact misleading to the extent that it suggests a dichotomy whereas the relationship between the 'formal constitution' and the 'material constitution' is better characterised as an internal or integrative one. Even an essentially sham constitution may have certain civilising effects on official behaviour; even an authoritarian regime may look to constitutional devices to secure its legitimacy or effectiveness in practice. ${ }^{144}$

An accurate understanding of the material constitution and its relation with the formal constitution offers important methodological insights for public and comparative constitutional lawyers. It prevents, for example, the collapse of the idea of constitutional change into the practice of formal constitutional amendment. Not every formal constitutional change is tantamount to a material transformation of the constitutional order, while constitutional transformations can also occur without any formal modification of the constitution. Two examples familiar to constitutional lawyers might help to assess the importance of the material constitution for constitutional studies. Switzerland enacted a new constitutional text in 1999. However, no one would suggest that this new document has brought about a material transformation of the constitutional order. ${ }^{145}$ The main principles and objectives of the Swiss constitution have remained the same. ${ }^{146}$ Conversely, significant constitutional change can occur without formal registration. During the fascist regime, although Italy was still formally governed by the Statuto Albertino (an octroyée and flexible constitution enacted in 1848), the material constitution had changed, giving rise to a new order which would be qualified by Italian public lawyers as the fascist regime (regime fascista). ${ }^{147}$ The old constitution was still considered valid, but within a completely different constitutional order. ${ }^{148}$

144 See e.g. T. Ginsburg and A. Simpser (eds.) Constitutions in Authoritarian Regimes (Cambridge University Press, 2014).

145 On the new constitution of Switzerland see F. Bellanger, 'Révision totale et partielle de la Constitution fédérale', in J.-F. Aubert, D. Thürer, P. Müller, Droit constitutionnel Suisse (Schulthess Verlag, 2001) 1247-1260.

146 Another interesting example may be represented by the extension of the Grundgesetz to the former Democratic Republic of Germany. It seems that despite the inclusion under the jurisdiction of the Basic Law concerned millions of citizens, there has not been a material or substantial change in the undergirding constitutional order. Cf H. Hofmann, La libertà nello Stato moderno (Guida, 2009) 20.

${ }^{147}$ Mortati noted the innovation brought about by the fascist regime in L'ordinamento del governo, above n. 62-68 and later in his textbook for comparative constitutional law: Forme di governo (Cedam, 1973) 82-85; see, also, the observations of an influential German scholar: G. Leibholz, $Z u$ den Problemen von des faschistischen Verfassungsrechtes (De Gruyter, 1928): cf S. Panunzio, Teoria Generale dello Stato fascista (Cedam, 1937) and, for a historical reconstruction, S. Cassese, Lo Stato fascista (Il Mulino, 2016).

${ }^{148}$ In the case of the US, few constitutional amendments have been added to the original text of the constitution, but the changes in the constitutional order have been of great importance. The classic reference is B. Ackerman, We the People: Transformations (Harvard University Press, 1998). 
Furthermore, the relation between material and formal constitution can shed light on the contiguous issue of the scale of legitimate constitutional change. Several constitutions around the world (and many constitutional or supreme courts) have in recent decades introduced explicit limits to constitutional amendment. At times, these limits have been reconstructed or inferred by courts (and other institutions) by looking at the wider constitutional order. In this way, a notion of unconstitutional constitutional amendments has been forged in order to manage cases of conflict between core principles of the constitution and new constitutional amendments (often formally approved). ${ }^{149}$ Of course, this is particularly problematic for constitutional orders based on a democratic form of government because the amendment to the constitution might have been approved by democratic means. Also, it is not clear how one might ground the limits to constitutional change in a purely normative way. The reference to a basic structure or the constitutional identity of a polity can indeed be conceived beyond a formalism or normativism. The main tenets of the material constitution might have been codified in a formal document (often in preambles), ${ }^{150}$ but they represent essential pillars for the whole constitutional order and, accordingly, are key defining traits of an order's constitutional identity. Therefore, the material constitution is not 'what happens' in the sense of sheer occasionalism; rather it delineates the conditions which make possible the emergence of a state of affairs as a concrete constitutional order. The knowledge of these conditions make it possible to draw a distinction between parts of a constitutional order whose change would be equivalent to the transformation of their identity and parts whose change, while important, could be seen as a reform or an augmentation of the constitutional order.

The ordering forces thus stands in internal relation to the formal constitutional settlement. Their formation (and fragility) cannot be ignored because they breathe life into the constitutional order and condition its development. Each gives a sense of direction to constitutional norms. Contrary to a view of political constitutionalism which portrays law and politics as incommensurable, in our analysis their relation is internal. Law cannot be considered just as the transmission belt of political decisions that are made before and outside the legal order. ${ }^{151}$ Neither can it be considered an apolitical constraint on political action.

\footnotetext{
149 The literature on this issue is growing enormously. For an original overview see, recently, Y. Roznai, Unconstitutional Constitutional Amendments (Oxford University Press, 2017): see, also, R. Albert, 'Constitutional Law and Disemberment' (2018) 43 Yale Journal of International Law forthcoming.

${ }^{150}$ Cf. W. Voermans, Constitutional Preambles: Comparative Perspectives (Elgar, 2017). Schmitt had also noted the juridical relevance of preambles: Constitutional Theory (Duke University Press, 2008) 78-79.

151 These remarks suggest that the integration of the material and the formal constitution would also provide important insights for constitutional interpretation. But this topic deserves a treatment on its own.
} 
The emphasis placed upon ordering forces is not to suggest that order is easily attained within the material constitution. On the contrary, our insistence on movement, conflict, and dynamism should signal that the material constitution depends on a variety of forces, frequently oppositional, that combine in the process of political unification, institution-building and the movement of pursuing fundamental political aims. For this reason, the constitution can be strengthened by institutionalising material contest, and even material conflict. But such conflict can become threatening, and existentially so.

To understand this process better, we can draw a distinction between two types of conflict and observe how they can be conceived from a material perspective. A first type of conflict, if properly institutionalised, can lead to further consolidation of the constitutional order. The constitution can be enhanced if it is able to manage conflict and display sensitivity to social forces and social conflicts, particularly those that could not have been foreseen at the moment in which the constitutional project was initiated. This also allows the constitution to mould society, making space for new social instances and inputs, which in turn gives the material constitution some elasticity and durability. This does not mean that everything can be accommodated, but it does mean that the animating movement of the material constitution, with its cascading effects on institutions, can be enabled by a type of conflict management. These conflicts often involve pressure placed by social and political forces upon the boundaries of institutions and political/social subjects, and test their capacity to accommodate new claims. They need not challenge the fundamental political aims of the constitutional order nor necessarily give rise to new constitutional subjects but rather redirect the existing constitutional dynamic.

A second type of conflict actually threatens the material constitution by testing the normative core supported by the dominant social and political forces. This happens when the dominant imprint is no longer able to exert pervasive effects throughout the political community. This might be the case when ruling forces no longer coalesce around the same political aims or when there are internal contradictions among these aims and a compromise cannot be found. When this happens, conflicts cease to be productive for the constitution and a far-reaching change of the material (and formal) order becomes pressing. At this stage, the state of exception acts as a signal that the material constitution and the relative condensation of political and social forces which support it are under a serious threat of dissolution and an extraordinary intervention is required. In other words, the exception is not an unexpected event that threatens from outside the normality of the legal order; on the contrary, the exception surfaces from within, when the material constitution is under threat. ${ }^{152}$

If the state of exception is considered legitimate when it aims at preserving the material constitution, 153 it makes little sense to consider it an extra-juridical

152 M. Croce, A. Salvatore, 'After Exception: Carl Schmitt's Legal Institutionalism and the Repudiation of Exceptionalism' (2016) 29 Ratio Juris 410.

${ }^{153}$ Loughlin, Foundations of Public Law, above 280. 
moment beyond the knowledge of constitutional lawyers. The same logic unfolds in other cases where the core of the material constitution is at stake. In the context of the European Union, for example, this became visible in the confrontation between highest national courts surrounding the penetration of EU law into national constitutional systems. Faced with the risk that certain measures provided for by EU law may unravel aspects of the social fabric and hence of core aspects of national constitutional identity, judges felt they had to set a threshold to be drawn along key constitutional principles. ${ }^{154}$ The development of the doctrine of 'counter-limits' by some national constitutional courts can be read as an exercise of guardianship of core aspects of the Member State's material constitution, bearing on political unity (national identity), institutional authority, and even social relations. ${ }^{155}$ Reference to the material (rather than the formal) constitution helps here in identifying the limits of constitutional revision or transformation. But this appeal to guardianship of the constitution may be made not only by constitutional courts, but other formal as well as informal actors, such as parliaments and even the people themselves, through social movements and political parties as well as referenda.

Recognition of the material constitution has conspicuous consequences. It enriches constitutional enquiry by revealing the material relations between law, politics and society undergirding the formal constitution and permits study of the state of exception, or the doctrines of counter-limits and constitutional identity (as well as other liminal figures of constitutional law such as the constituent power) through its prism. The concept of the material constitution captures the internal relation between constitutional order and society without, however, eliding its conflictual and evolving nature. It is through this dynamic that constitutional change occurs. We have offered here an account of its four layers, the 'ordering forces' of the constitution and the relationships among them. If constitutional theory is to avoid the risk of becoming irrelevant in its abstractions, it will have to grapple with questions of material ordering and re-ordering. All the more so as we enter a period when formal constitutionalism is beginning to look divorced from constitutional reality, and constitutional order is, once again, threatened by radical change.

154 See especially the Lisbon decision of the German Constitutional Court, BVerfG, 2 BE 2/08, 30 June 2009.

155 This doctrine has been developed by the German and the Italian constitutional courts: cf V Barsotti, P Carozza, M Cartabia, A Simoncini, Italian Constitutional Justice in the Global Context (Oxford University Press, 2016) 214-217. 